\title{
Ajuste de cuentas con los cuentos
}

Alejandra Silva Lomelí Centro de Enseñanza para Extranjeros, UNAM

El libro Ajuste de cuent@s es el resultado del esfuerzo perseverante que los autores antologados le han dedicado al arte de la escritura. Autores que, es importante mencionar, son todos alumnos del Taller de creación literaria que se imparte en el Centro de Enseñanza para Extranjeros de la UNAM, un espacio en el que han adquirido no solamente el conocimiento teórico y las técnicas necesarias para concebir obras literarias, sino la pericia de la crítica y la expresión del comentario constructivo que derive en el perfeccionamiento del trabajo creativo. El maestro Felipe Garrido, notable escritor y académico, es quien ha guiado a los autores de Ajuste de cuent@s en el proceso, complejo y satisfactorio, de convertirse en escritores.

El coordinador de un taller de creación literaria es, casi por definición, una persona generosa, pues comparte con los talleristas los secretos de su oficio, la experiencia de años, las lecturas realizadas y el conocimiento adquirido, y quizá también comparta con ellos sus inquietudes e incertidumbres, que muchas veces son las que motivan el estudio y el aprendizaje. Un buen maestro también se caracteriza por ser paciente, por acompañar a sus estudiantes durante desarrollo de sus habilidades y su formación, un camino que frecuentemente se recorre entre tropiezos y frustraciones, pues en ocasiones es necesario deshacerse del trabajo fallido y volver a empezar. Y ante la adversidad es muy fácil desistir. Un buen maestro sabe que es necesario encontrar un equilibrio entre impulsar la confianza del estudiante y darle la libertad para que encuentre su propio estilo, para que explore nuevas formas de expresión literaria, y por otro lado recordarle que el perfeccionamiento de la técnica es inagotable, que siempre hay algo nuevo por aprender, que los grandes escritores lo han sido precisamente porque entendieron que las posibilidades son infinitas y saben que las obras literarias, como quienes las producen, necesitan tiempo para madurar.

El destacado escritor veracruzano Luis Arturo Ramos, uno de los iniciadores del Programa de Maestría en Escritura Creativa de la Universidad de Texas en El Paso, nos comparte su amplia experiencia como coordinador de este tipo de talleres en su texto "La enseñanza de la creación literaria: ritos y retos", publicado en el número 71 de la Revista de Literatura Mexicana Contemporánea y en donde define la tarea del mentor con estas palabras: 
[...] mucho [de la] credibilidad [del] asesor deriva de su propia experiencia escritural en el género o géneros de su preferencia. Es el maestro en los términos que los gremios medievales le daban al encargado de enseñar el oficio que los distinguía. Sólo un buen panadero o carpintero o herrajero podía tener aprendices. No para copiar su sapiencia, sino para verse influidos por la manera de ejercerla en el oficio en el que habían destacado sus mentores. Y es su capacidad de compartir esa experiencia significada en los trucos, las intuiciones y los meditados atrevimientos lo que convierte a cualquier practicante del oficio en un buen maestro.

De esta manera, la publicación de la antología Ajuste de cuent@s pone de manifiesto el fructífero trabajo que el maestro Felipe Garrido ha dedicado a sus discípulos.

Ajuste de cuent@s reúne a diez autores y nos ofrece 47 cuentos, cada uno de ellos, por supuesto, con una marca particular, un estilo propio y una propuesta original. Conforme avanzaba en la lectura me percaté de que varios relatos comparten temas específicos: la muerte, la enfermedad, el abuso, la desesperanza, el crimen, el amor y el desamor, la nostalgia, la crueldad, las obsesiones, el erotismo, la soledad, el rencory la culpa constituyen el eje temático de un grupo de narraciones aquí contenidas. Estos asuntos son, como bien sabemos, motivo de incontables obras no solamente literarias, sino artísticas en general, eso sin contar los trabajos filosóficos, antropológicos, de la psicología y de otras áreas afines. Lograr la originalidad y un estilo propio en la creación de un cuento con alguno de estos temas es, por eso mismo, doblemente meritorio.

La antología inicia con los textos de Juan Manuel Bueno, cuya cuidada escritura se dedica a construir ambientes bien logrados y situaciones que sorprenden al lector por la manera en que llegan a un final inesperado. La presencia de algunos intertextos reconocibles en sus cuentos revela su calidad de buen lector.

Arturo Garmendia, quien compiló este volumen y elaboró la nota introductoria, aparece a continuación con cuatro títulos, aunque uno de ellos, "Cuentos bonsái", contiene en realidad una serie de microcuentos que, como el nombre indica, manifiestan un trabajo esmerado, con un notable sentido de lo estético y, como los árboles bonsái, son bellos y completos en su brevedad. Los cuentos de Arturo son entrañables y resalta el buen manejo del lenguaje con el cual fueron construidos. Como jardinero de bonsái, va podando hasta mostrar la esencia de sus historias.

La recreación de espacios y personajes provincianos sale de la pluma de Virginia Lara Sánchez, quien ofrece atmósferas y situaciones que seguramente remitirán al lector a su infancia, posiblemente transcurrida en casas de zaguanes abiertos y ventanas dispuestas a recibir las visitas de vecinas indiscretas que llevaban y traían las últimas noticias de personas cercanas o francamente 
desconocidas. La narrativa de Virginia logra trasladar al lector a un espacio añorado e irrecuperable.

Normairene Matamoros nos enfrenta a la narración de situaciones tristemente cotidianas pero que han sido injustamente ocultas. Me refiero a la violencia y múltiple victimización que viven las mujeres, quienes no sólo se encuentran continuamente en situaciones de vulnerabilidad, abuso y agresión, sino que afrontan la burla y los prejuicios, cuando no la incredulidad y la sospecha. Normairene perfila con esmero a sus personajes femeninos, uno de los cuales resulta especialmente entrañable: esta mujer que, en su intento por liberarse, paradójicamente se sigue sujetando a los valores de conducta que la sociedad le ha impuesto.

La nostalgia, el duelo, la narración de la propia muerte, las obsesiones y los deseos frustrados se expresan en los cuentos de Elios Mitre, cuyo estilo cautiva no solamente por la construcción de los espacios y las atmósferas, tan bien logradas, sino sobre todo por la minuciosidad con que crea a sus personajes, algunos de los cuales enternecen por su candidez, otros conmueven por la adversidad que enfrentan, y otros más nos provocan risa y sorpresa al mostrarnos su astucia.

Lorena Páez nos ofrece cuatro cuentos, el primero de los cuales se titula "La copra" que, según el diccionario, es la "médula del coco de la palma", y esto es muy significativo pues los cuentos que le siguen se caracterizan también por una especie de médula: la narración de la cruda violencia que experimentan las mujeres de manera habitual y el sentimiento de culpa imborrable con que viven quienes han sido victimizadas múltiples ocasiones. El abuso sexual, el engaño y el autoengaño son los motivos temáticos de las historias de Lorena, las cuales consiguen su cometido: perturban no solamente por la crueldad narrada, sino porque reconocemos en sus líneas anécdotas vigentes, cercanas y reales que no nos pueden mantener imperturbables.

Luis Alberto de la Peña nos presenta tres cuentos que se caracterizan, entre otros aspectos, porque su singular empleo de las estrategias narrativas logra crear en el lector el efecto de que se encuentra ante un tiempo fragmentado que se repite. Luis Alberto sabe, además, escuchar a sus personajes, destreza que considero sumamente importante pues son ellos quienes deben exigirle al autor el empleo de un lenguaje apropiado que los distinga según sean sus circunstancias, historias de vida, ideología, educación y entornos. Luis Alberto logra de manera notable que sus personajes sean convincentes, por lo que al finalizar la lectura los reconocemos como individuos cercanos, casi íntimos.

Los cuentos de Ariel Quintero destacan por el adecuado manejo de las voces narrativas. La expresión desde el Yo, esa voz en primera persona que acerca al lector a la experiencia más entrañable, nos transmite la inquietud y la zozobra que se instala en la consciencia más profunda, aquella que se revela en el insomnio 
y en los momentos más inesperados. El lenguaje preciso con que construye su cuento "Herida imborrable"le permite a quien se acerque a estas páginas penetrar en la consciencia figural y percibir el temor que invade al personaje, así como sus motivos para huir de la justicia tras haber cometido un crimen.

Hilda Tapia, por su parte, lleva a sus personajes al límite, esa instancia en la que se revelan dos opciones: sucumbir ante la adversidad o expulsar las culpas, los rencores y los remordimientos para trazar nuevos trayectos, para que el personaje mire el entorno y perciba lúcidamente, quizá por primera vez, lo que lo rodea. Por esta razón, los cuentos de Hilda nos llevan a reflexionar sobre nuestro propio proceder y lugar en el mundo.

El libro cierra con la participación de Lourdes Ulloa, cuyos relatos están protagonizados por personajes complejos que transitan por penosos conflictos que son narrados con un lenguaje fluido, mismo que, paradójicamente, resalta el desasosiego de quienes participan de la historia. Los ambientes, el manejo del tiempo narrativo y la adecuada función de las voces narrativas en los cuentos de Lourdes logran que el lector se concentre en el sinuoso devenir de los personajes.

Ajuste de cuent@s es un libro colectivo que se conforma de particularidades y rasgos únicos. Cada uno de sus autores da al conjunto una aportación valiosa y original que manifiesta la amplia gama de intereses y filias que se reúnen en estas páginas. Celebro la aparición del volumen, pues pone en nuestras manos el resultado de infatigables horas de trabajo en las que se concibieron historias que posteriormente tomarían forma en las páginas; proyectos que fueron compartidos en el Taller con el objetivo de que fueran valorados, transformados, corregidos o quizá reescritos en su totalidad. Todo este empeño, minucioso como el trabajo de un orfebre, se concreta en estos cuentos que son dignos de ser antologados y que ahora aguardan la lectura de su público. 
Decires es una publicación editada en línea y de libre acceso alojada en www.revistadecires.cepe.unam.mx del Centro de Enseñanza para Extranjeros de la UNAM. Ciudad Universitaria, primer semestre 2018. 
